MARIJA ŠEGAN-RADONJIĆ

Mathematical Institute SANU

Belgrade, Serbia

E-mail:msegan@mi.sanu.ac.rs

MILICA TAPAVIČKI-ILIĆ

Institute of Archaeology

Belgrade, Serbia

E-mail:mtapavic@sbb.rs
Received: October $31^{\text {st }} 2020$

Accepted: December $10^{\text {th }} 2020$

Original research article

902/904:004(497.11)"1990/..."

COBISS.SR-ID 29142537

https://doi.org/10.18485/arhe_apn.2020.16.12

\title{
SERBIAN ARCHAEOLOGY IN DIGITAL ERA - THE STATE OF THE ART
}

\begin{abstract}
The paper gives an overview of cultural heritage digitization in the Republic of Serbia. Ever since 1990-ties, there have been various attempts to digitize parts of Serbia's cultural heritage. These included both artefacts kept at various museums or data gained during specific archaeological excavations. However, those attempts were conducted as isolated cases. In recent years, digitization of cultural heritage has become an imperative for all of the institutions that deal with it. This is why there are attempts to establish a strategy at the national level and implement it throughout the country. Although the goal is to digitize Serbian cultural heritage, special attention needs to be paid to accessibility, since digitized data are easy to misuse. Further on, over-digitization should also be prevented. Therefore, it is necessary to define how, why and to what extent pieces of cultural heritage need to be digitized.
\end{abstract}

KEYWORDS: ARCHAEOLOGY, SERBIA, DIGITIZATION, DIGITAL, DATA, REGULATION, ARTEFACT, OVERVIEW.

\section{INTRODUCTION}

This paper deals with identifying existing research and projects about digitization and electronic management of archaeological heritage and protective institutions in Serbia (by the term "cultural heritage institutions" the authors refer to museums, archives, libraries and institutes for the protection of cultural monuments). Paper deals with the period from introducing computer technology and information systems into the protective institutions in Serbia during the late eighties of the $20^{\text {th }}$ century until recent efforts of the Serbian Ministry of Culture and Information to regulate processes of digitizing cultural heritage and dig- ital transformation of the protecting institutions. This overview aims to assist all the researchers interested in comprehending the existing state of the art and to highlight potential challenges, as well as potentials for future research in the area of managing cultural heritage.

In accordance with "The Law on Cultural Heritage" (Службени гласник РС, 71/1994) and "The Law of acceptance of the European Convention for Protection of Cultural Heritage" (Службени гласник РC, 42/2009) in this paper, the term "archaeological heritage" includes archaeological research and excavations, archaeological sites, archaeological artefacts and archaeological documentation. According to „The Law on Cultural 
Heritage“, archaeological heritage, most of all archaeological sites, can be categorized as established cultural property (established by the government of the Republic of Serbia) or as real estate enjoying prior protection (established by the Institute for Protection of Cultural Monuments) (Службени гласник РС, 71/1994), regarding the fact that processes for the acknowledgement of cultural heritage is often rather long-lasting. ${ }^{1}$ Further on, in the Republic of Serbia, archaeological research and excavations can only be conducted by institutions specialized in protection (institutes for protection of cultural monuments and museums) ${ }^{2}$ and scientific institutions (faculties and institutes), ${ }^{3}$ both with the approval of the Ministry of Culture and Information (Ibid.; "Request Form Template for archaeological excavations and research," 2020). Finally, the process of documenting archaeological heritage is regulated by law. ${ }^{4}$ In May 2020, the new regulation on documenting was accepted, regarding archaeological excavations and research (Службени гласник РС, 67/2020). It can be concluded that managing archaeological heritage in the Republic of Serbia is conducted by the government and its departments ${ }^{5}$

1 It is stated for example that in Serbia there are more than 20.000 archaeological sites (Crnobrnja, 2019). However, in the priod from 1948 until present time, only 194 have been recorded (see Central Register of Archaeological Sites in Republic of Serbia); eleven of them were categorized as cultural heritage of great importance and twenyfive as cultural heritage of big importance (see Immovable Cultural Property - IMP).

2 There are one Central Institute for Protection of Cultural Monuments (at the national level) and thirteen Regional Institutes for Protection of Cultural Monuments (two at the provincial level, two at the city level and nine at the regional level) (see Drača Muntean, ibid; Network of Institutes in Serbia), as well as Cultural Heritage Museums.

3 There is the Institute of Archaeology of the Serbian Academy of Sciences and Arts and Department of Archaeology at the Faculty of Philosophy, University of Belgrade.

4 See e. g. "The Law on Cultural Heritage (1994) or Rules on the forms for documents kept on archaeological excavation and research (2006).

5 It is managed at three different levels: state (e.g. Ministry of Culture and Information, Sector for Cultural Heritage Protection), provincial (e.g., Provincial Institutes for Protection of Cultural Monuments, Provincial Secretariat for Culture and Public Information) and local level (e.g., and mostly financed from the state budget.6 At one hand, this means stability and security, but on the other hand, lack of autonomy" (DragićevićŠešić 2018: 78).

The focus of this paper is digitization and electronic management of archaeological heritage in the Republic of Serbia. The new regulation on documenting archaeological research prescribes that documenting should be conducted electronically, within a unique information system for keeping incorporated archaeological documentation (Службени гласник PC, 67/2020) that should be secured by the Ministry of Culture and Information in order to "incorporate data and information accessibility for institutions of protection and other state institutions" (Службени гласник РС, 76/2018). Although these regulations are rather new and until recently, it was expected that archaeological documentation should be kept on physical forms in the shape of cards and sheets exclusively (Службени гласник PC, 102/2006), the authors tend to show that the idea of digitization and electronic management of archaeological heritage in Serbia is several decades old and they also want to identify efforts in its conducting.

Digitization of cultural heritage is a relatively new field of research and due to its dynamic development there is still no general definition (Ognjanović 2019). Since in its early developing phases it was technologically determined and conditioned, it was regarded exclusively as

regional and local government / museums / institutes) (Drača Muntean, ibid).

6 In Serbia, funding projects in the field of cultural heritage "can be divided into three subgroups: budgetary financing, financing from the European pre-accession funds and financing through the private sector, corporate philanthropy and corporate social responsibility" (Drača Muntean, n.d.). It is estimated that protecting institutions in Serbia "get more than $90 \%$ of the funding from the Ministry" (Cvijetičanin cited in Dragićević-Šešić, 2018, 78), out of which $50 \%$ goes on salaries and mere functioning of institutions (Ibid.). When it comes to archaeological research in Serbia, an information has been revealed that in the period from 2018 until 2020, some $11 \%$ of the total budget of the Ministray of Culture and Information has been assigned for protection of cultural heritage (Ministry of Culture and Information of the RS, August 28 ${ }^{\text {th }}, 2020$ ). 
a converting process of analogue contents into their digital form, into a row of zeros and aces that could be recognized by a PC (Hughes 2004: 4). In the meantime, it overgrew technical issues of converting and it became a complex procedure of managing cultural heritage in a technological environment, encompassing philosophical, social, cultural and economic aspects and consequences (Manžuch 2005: 37). With regard to the choice of objectives, technologies, standards or funding models, this process varies from organization to organization, from country to country. When it comes to the Republic of Serbia, it is defined as a comprehensive procedure for managing cultural heritage in the digital environment, which includes, but is not limited to, translation from analogue to digital form; establishing a metadata system and a description of digitized and digital material; development of tools, electronic catalogues and information systems and long-term preservation, presentation and providing access to data (Ognjanović 2019). This procedure is recognized as part of a complex system of preservation and management of cultural heritage in cultural heritage institutions in Serbia (Ognjanović 2019).

The rest of the paper is structured as follows: Part 2 reveals an overview of information system development within protecting institutions (cultural heritage institutions) in Serbia. Part 3 shows a brief history of digitizing cultural heritage in Serbia. Part 4 deals with the issue of regulating digitizing processes in protecting institutions in Serbia. Part 5 includes a conclusion.

\section{OVERVIEW OF CULTURAL (ARCHAEO- LOGICAL) HERITAGE INFORMATION SYSTEMS IN SERBIA}

The main activities of the cultural heritage institutions in Serbia include documenting and preserving cultural heritage ("Law on Culture," 2009). Documenting is understood as "an organized process of recording information possessed and emitted by objects and units of heritage" (Maroević 1993: 190). Numerous information languages and systems for analyzing, indexing and storing information have been established so far, with "the goal of their subsequent successful locating, transfer and exchange" (Crvčanin 1983: 9). Development and wider use of personal computers in the 1990s transformed the environment in which data is created, searched, interpreted and stored, hence the need emerged for simpler practices of documenting.

In the Republic of Serbia, ${ }^{7}$ there is a decades-long practice of documenting cultural heritage in an electronic environment, but the challenge is to monitor continuity of its development because research on this subject varies from area to area. ${ }^{8}$ Apparently, activities on the development of Scientific and Technological Information System of Serbia (SNTIS) in the early 1990s gave impetus to the development of centralized computer networks, information systems and national databases. ${ }^{9}$ In order to identify information systems

7 It should be borne in mind that in the period up to 1992 the Republic of Serbia was part of the Socialist Federal Republic of Yugoslavia, from 1992 to 2003 part of the Federal Republic of Yugoslavia, from 2003 to 2006 part of the State Union of Serbia and Montenegro, and since 2006 an independent state, as the Republic of Serbia.

8 There are detailed historical reviews of the automatization process in the field of library science in Serbia (see, among others, Kosanović 1996; Trtovac 2017). However, the authors could not find similar historical reviews related to automatization and digitization in the field of archaeology.

9 The Strategy of the System of Scientific and Technological Information of Serbia (SNTIS), adopted in 1991, was derived from the concept of the Scientific and Technological Information System of Yugoslavia (SNTIJ) presented in 1987, as well as the accompanying analysis published in 1988 (see "The system of scientific and technological information of Yugoslavia: a feasibility study", 1988). Unlike SNTIJ, that aimed at centralizing development and construction of a homogeneous computer network with a single central "host", SNTIS was conceived as a distributed information system that "should connect academic and other scientific research through appropriate computer network and documentation organizations and enable connection with similar systems and networks in the world" (Lazarević 1996, I) Therefore, SNTIS, as a set of a number of local networks and subsystems with a single physical computer-communication network based on public PTT traffic, was supposed to enable each organization to be- 
used in cultural heritage institutions in Serbia in the period from 1987 to 2018, Chart 1 provides an overview of the most widely used systems with an emphasis on institutions responsible for management and preservation of archaeological documentation and heritage. (It should be kept in mind that in 2018 a special law was issued in Serbia obliging these institutions to implement specific information systems. This issue is further discussed in Section 4.) According to the data given in Table 1 and regarding development of information systems within Serbian institutions for protection, four phases can be identified. The first phase includes the period from 1987 to 1995. During this phase, initial strategies about implementing information systems were developed, while institutions form protections (mostly libraries) cooperated with software companies and developed and introduced some aspects of information systems based on DOS and Unix operating systems (Fig. 1). Unfortunately, due to the lack of means for purchasing equipment, the lack of support, educated experts and quick technological development, these solutions did not last very long. During the next phase, from 1995 to 2000, the awareness of information systems' importance grew bigger. This is why apart from libraries, also museums, archives and institutes for protection of cultural heritage sought cooperation with software companies or scientific institutions and developed and tested pilot systems based on Windows/Linux operating systems. Just like in the previous phase, the main challenges of this phase included lack of understanding from the leading positions, the lack of equipment and educated experts and incapability of exchanging data. The following period from 2000 to 2018 is marked with upgrading the existing and developing new solutions, as well as orientating towards Web operating systems. However, although the focus lied on achieving uniformity, there was no coordinating mechanism and this is why the implemented systems differ re-

come part of it and to define and realize its own role in it, in accordance with general development plans (Ibid.). garding applied technologies and standards. This is why the Ministry of Culture and Information is trying to establish regulations about information systems within institutions of protection, thus marking the beginning of a new phase (about this see Part 4). Table 1 also shows that the Institute of Archaeology SASA was the only institution that considered specialized information systems in archaeology, although these considerations remained at the level of pilot projects.

\section{OVERVIEW OF CULTURAL (AR- CHAEOLOGICAL) HERITAGE DIGITIZATION IN SERBIA}

The wider use of personal computers, global computer network and Web browsers have given impetus to development of digitization of cultural heritage in Europe and therefore also Serbia. The earliest attempts in this field were made in the mid-1990s (Ognjanović 2019). When it comes to digitization of archaeological heritage, apart from pioneering models of electronic archaeological databases (Korać 1994), one needs to mention the project PANDORA implemented in 1995-1996 in cooperation with the Institute of Archaeology SANU and the Mathematical Institute SANU. This project is considered the first one in digitization of cultural heritage in Serbia (Mijajlović 2002: 12) and its goal was to create a prototype of an expert system for dating archaeological material based on digitization of available archaeological sources (Korać 2006b: 119). It was inspired by similar systems in the field of medicine (i.e. MYCIN expert system) and despite the fact that it was not fully implemented (Radio Television of Serbia, November 2019), it gave a boost to the wider use of new technologies in the field of culture. Thus, for instance, the next endeavour of the Institute of Archaeology SANU and Mathematical Institute SANU was digitization of selected collections of the Belgrade City Museum and the storage of digitized content on optical discs 
Chart 1 Overview of information system in institutions for protection (1987-2018).

\begin{tabular}{|c|c|c|c|c|}
\hline Year & Title & Institution & Technology & Users \\
\hline \multirow[t]{2}{*}{1987} & $\begin{array}{c}\text { Library } \\
\text { Information } \\
\text { System (BIS) } \\
\text { of Scientific- } \\
\text { Technological } \\
\text { Information } \\
\text { System of } \\
\text { Yugoslavia } \\
\text { (SNTIJ) }\end{array}$ & $\begin{array}{c}\text { Institute of } \\
\text { Information } \\
\text { Science Maribor } \\
\text { (IZUM) }\end{array}$ & $\begin{array}{c}\text { ATLASS software platform; } \\
\text { homogeneous computer } \\
\text { network of VAX-Digital } \\
\text { computers; centralized } \\
\text { databases; UNIMARC } \\
\text { format (Lazarević 1996: 2; } \\
\text { Trtovac 2017: 105) }\end{array}$ & $\begin{array}{l}\text { Up until 1992, around } 30 \\
\text { libraries in Serbia were } \\
\text { included in the system } \\
\text { of mutual cataloguing. } \\
\text { (Trtovac 2017: 105-107) }\end{array}$ \\
\hline & $\begin{array}{c}\text { Library } \\
\text { Information } \\
\text { System of the } \\
\text { Belgrade City } \\
\text { Library }\end{array}$ & $\begin{array}{c}\text { Belgrade City } \\
\text { Library Energodata }\end{array}$ & $\begin{array}{l}\text { BIBLIS computer program; } \\
\text { Xenix operating system } \\
\text { (Petrović 2002: 190) }\end{array}$ & Belgrade City Library \\
\hline 1989 & $\begin{array}{c}\text { Information } \\
\text { System for } \\
\text { Archaeology (ISA) }\end{array}$ & $\begin{array}{c}\text { Institute of } \\
\text { Archaeology of the } \\
\text { Serbian Academy } \\
\text { of Sciences and } \\
\text { Arts (SASA) } \\
\text { (Korać 1991b: } \\
287 \text { ) }\end{array}$ & & \\
\hline \multirow{2}{*}{1991} & $\begin{array}{c}\text { Library } \\
\text { Information } \\
\text { System of the } \\
\text { Belgrade City } \\
\text { Library }\end{array}$ & $\begin{array}{l}\text { Belgrade City } \\
\text { Library } \\
\text { OSA computer } \\
\text { engineering }\end{array}$ & \begin{tabular}{|c|} 
LIBNET computer \\
program; Clipper \\
programming language; \\
MS-DOS operating system \\
(Petrović 2002: 190)
\end{tabular} & Belgrade City Library \\
\hline & $\begin{array}{l}\text { Proposal for } \\
\text { application } \\
\text { AGORA BBS }\end{array}$ & $\begin{array}{l}\text { Institute of } \\
\text { Archaeology } \\
\text { SASA }\end{array}$ & $\begin{array}{l}\text { Online Bulletin Board } \\
\text { System } \\
\text { (Korać 1991a: 31-41) }\end{array}$ & \\
\hline 1994 & $\begin{array}{l}\text { Archaeological } \\
\text { database model } \\
\text { proposal }\end{array}$ & $\begin{array}{l}\text { Institute of } \\
\text { Archaeology } \\
\text { SASA }\end{array}$ & $\begin{array}{c}\text { Clipper; MS-DOS operating } \\
\text { system (Korać 1994) }\end{array}$ & \\
\hline
\end{tabular}




\begin{tabular}{|c|c|c|c|c|}
\hline \multirow{3}{*}{1996} & $\begin{array}{c}\text { Library subsystem } \\
\text { SNTIS }\end{array}$ & $\begin{array}{c}\text { A group of } \\
\text { institutions led } \\
\text { by the Faculty of } \\
\text { Natural Sciences } \\
\text { and Mathematics } \\
\text { of the University } \\
\text { of Novi Sad }\end{array}$ & $\begin{array}{c}\text { BISIS v1.0 Library } \\
\text { Software System based } \\
\text { on CDS / ISIS program } \\
\text { developed by UNESCO; } \\
\text { programming language C; } \\
\text { database db Vista; operating } \\
\text { systems UNIX, DOS, VMS, } \\
\text { Windows; UNIMARC } \\
\text { format. (Lazarević 1996: } \\
\text { 6-8) }\end{array}$ & $\begin{array}{l}\text { Until } 2019 \text {, this system, i.e. } \\
\text { its improved versions (the } \\
\text { latest version is version } \\
\text { 5) were used in } 33 \text { public } \\
\text { libraries at the territory } \\
\text { of the Republic of Serbia. } \\
\text { ("Libraries in the BISIS } \\
\text { System," n.d.) }\end{array}$ \\
\hline & $\begin{array}{c}\text { Information } \\
\text { System of Cultural } \\
\text { Monuments } \\
\text { (SINS) }\end{array}$ & $\begin{array}{c}\text { Republic Institute } \\
\text { for the Protection } \\
\text { of Cultural } \\
\text { Monuments }\end{array}$ & $\begin{array}{l}\text { Alphanumeric User } \\
\text { Interface } \\
\text { (Temerinski 2002: 52) }\end{array}$ & \begin{tabular}{|c|} 
Even though the first \\
proposal was in 1993, out \\
of eleven SINS modules, \\
only two were established \\
in 1996 - records of cultura \\
monuments and records \\
of exports of movable \\
cultural property. Since the \\
system used alphanumeric \\
user interface, it was soon \\
replaced by new proposal \\
in 1999. (Temerinski 2002: \\
52-53) \\
\end{tabular} \\
\hline & $\begin{array}{c}\text { Museum } \\
\text { Information } \\
\text { System of } \\
\text { Serbia (MISS): } \\
\text { Information } \\
\text { subsystem Central } \\
\text { Registry (CR) }\end{array}$ & $\begin{array}{l}\text { National Museum } \\
\text { in Belgrade }\end{array}$ & $\begin{array}{c}\text { Clipper programming } \\
\text { language; MS-DOS } \\
\text { operating system; Museum } \\
\text { Documentation Association } \\
\text { (MDA) standard for } \\
\text { museum object information } \\
\text { (Gavrilović 2015: } 2)\end{array}$ & $\begin{array}{l}\text { A total of } 46 \text { museums on } \\
\text { the territory of RS were } \\
\text { included until } 2009 \text {, when } \\
\text { this system ceased to be } \\
\text { used (Gavrilović 2015: 2). }\end{array}$ \\
\hline \multirow[b]{2}{*}{1999} & $\begin{array}{c}\text { Proposal for } \\
\text { application of } \\
\text { SUPERBASE for } \\
\text { Archaeologists }\end{array}$ & \begin{tabular}{|c|} 
Institute of \\
Archaeology \\
SASA \\
National Museum \\
in Požarevac \\
\end{tabular} & $\begin{array}{c}\text { Windows-based Database } \\
\text { Management Systems } \\
\text { (Korać, 1999). }\end{array}$ & \\
\hline & $\begin{array}{l}\text { Proposals for an } \\
\text { Electronic } \\
\text { Documentation } \\
\text { Center (DEC) }\end{array}$ & $\begin{array}{c}\text { Republic Institute } \\
\text { for the Protection } \\
\text { of Cultural } \\
\text { Monuments }\end{array}$ & MS Access & $\begin{array}{l}\text { The idea to create a Web } \\
\text { based Information System } \\
\text { was partialy established } \\
\text { in 2001, as Data Base of } \\
\text { Conditions and Protective } \\
\text { Measures of Monuments } \\
\text { Sites was implemented } \\
\text { (Temerinski 2002: 53). }\end{array}$ \\
\hline
\end{tabular}




\begin{tabular}{|c|c|c|c|c|}
\hline 2002 & $\mid \begin{array}{l}\text { Integrated museum } \\
\text { information system }\end{array}$ & $\begin{array}{c}\text { Historical Museum } \\
\text { of Serbia }\end{array}$ & \begin{tabular}{|} 
IMUS software program; \\
Museum Documentation \\
Association (MDA) \\
standard for museum object \\
information, Spectrum, \\
CIDOC CRM Reference \\
model (Bojković 2016: 52; \\
Vulikić 2018).
\end{tabular} & $\begin{array}{c}\text { Since } 2007 \text {, this system } \\
\text { has been jointly developed } \\
\text { by the Historical Museum } \\
\text { of Serbia and the Museum } \\
\text { of Vojvodina, and until } \\
2018 \text {, this system, i.e. its } \\
\text { improved versions were } \\
\text { used by } 32 \text { museums or } \\
34 \% \text { of museums in Serbia } \\
\text { (Vulikić 2018). }\end{array}$ \\
\hline 2003 & $\begin{array}{c}\text { Virtual Library of } \\
\text { Serbia (VBS) }\end{array}$ & \begin{tabular}{|} 
National Library of \\
Serbia \\
The Matica Srpska \\
Library \\
Svetozar Marković \\
University Library
\end{tabular} & $\begin{array}{c}\text { COBISS software platform } \\
\text { developed by IZUM in } \\
1991 \text { as the successor to } \\
\text { ATLASS; COBISS.net } \\
\text { network; COBISS.SR } \\
\text { mutual catalogue; COBIB. } \\
\text { SR database; formats based } \\
\text { on UNIMARC format } \\
\text { ("COBISS Platform," } \\
\text { 2016). }\end{array}$ & $\begin{array}{c}\text { In 2020, a total of } 223 \\
\text { libraries in Serbia are } \\
\text { included in this system, i.e. } \\
\text { in its improved versions. } \\
\text { ("COBISS.Net in } \\
\text { numbers," 2019) }\end{array}$ \\
\hline 2009 & $\begin{array}{c}\text { Museum } \\
\text { Information } \\
\text { System of Serbia } \\
\text { (MISS): database }\end{array}$ & \begin{tabular}{|} 
National Museum \\
in Belgrade \\
"Software \\
Information \\
Systems" Belgrade
\end{tabular} & $\begin{array}{l}\text { MS SQL Server } 2008 \\
\text { r2 relational database, } \\
\text { Microsoft Access-based } \\
\text { Desktop application } \\
\text { (Gavrilović 2015: 2) }\end{array}$ & $\begin{array}{l}\text { Used by } 33 \text { museums in } \\
\text { Serbia. } \\
\text { (Gavrilović 2015: 2) }\end{array}$ \\
\hline 2011 & \begin{tabular}{|c|} 
Museum \\
Information \\
System of Serbia \\
(MISS): Eternitas \\
web application \\
\end{tabular} & $\begin{array}{c}\text { National Museum } \\
\text { in Belgrade }\end{array}$ & $\begin{array}{c}\text { Web application; } \\
\text { programming language C \#; } \\
\text { open source } \\
\text { (Gavrilović } 2015: 3-4)\end{array}$ & \\
\hline 2014 & $\begin{array}{l}\text { ZIMUS } \\
\text { Information } \\
\text { System }\end{array}$ & $\begin{array}{c}\text { Museum of } \\
\text { Vojvodina Institute } \\
\text { for the Protection } \\
\text { of Cultural } \\
\text { Monuments of the } \\
\text { City of Novi Sad }\end{array}$ & $\begin{array}{c}\text { ZIMUS software package } \\
\text { for cataloguing and } \\
\text { digitizing documentation on } \\
\text { immovable cultural heritage } \\
\text { (Vulikić 2018) }\end{array}$ & $\begin{array}{l}\text { Used by } 2 \text { institutes for } \\
\text { the protection of cultural } \\
\text { monuments in Serbia } \\
\text { (Vulikić 2018) }\end{array}$ \\
\hline
\end{tabular}




\begin{tabular}{|c|c|c|c|}
\hline 2018 & $\begin{array}{c}\text { Rulebook } \\
\text { on Detailed } \\
\text { Conditions for the } \\
\text { Digitization of } \\
\text { Cultural Heritage }\end{array}$ & $\begin{array}{c}\text { Ministry of Culture } \\
\text { and Information }\end{array}$ & $\begin{array}{l}\text { This act obliges libraries } \\
\text { to use the unique system } \\
\text { managed by the National } \\
\text { Library of Serbia; archives } \\
\text { to implement a unified } \\
\text { Information System } \\
\text { for Archives (ARHIS) } \\
\text { managed by the Archives } \\
\text { of Serbia; museums to } \\
\text { implement a unified } \\
\text { Information System } \\
\text { (IMUS) managed by the } \\
\text { Historical Museum of } \\
\text { Serbia; and institutes for } \\
\text { the protection of cultural } \\
\text { heritage to use the system } \\
\text { developed and managed by } \\
\text { the Republic Institute for } \\
\text { the Protection of Сultural } \\
\text { Monuments (Cлужбени } \\
\text { госник РС 76/2018) }\end{array}$ \\
\hline
\end{tabular}

(Mijajlović, Novaković 2002: 43). ${ }^{10}$ It should be mentioned that the term 'digitization' was not used in this period, nor did the participants in these projects declare themselves as digitization experts (Mijajlović 2002: 25). These included archaeologists, museologists, archivists, librarians, computer scientists and mathematicians who examined, through joint ventures, the possibilities of interdisciplinary cooperation in creating infrastructures for preservation and presentation of cultural heritage in electronic form (Ognjanović 2019).

At the beginning of the 21 st century, the term and concept of digitization of cultural heritage has entered into wider usage in Serbia under the influ-

10 Although literature offers no information, it appears that this project was directly or indirectly inspired by the projects of the Library of Congress in Washington, D.C., which has stored its digitized collections on optical discs since 1980s (Andre 1989: 327; Cohen 2005). From 1994 it has made them available on the Web (Cohen, 2005). Its project "Making of America" was a great success and inspired many other cultural institutions around the world to digitize and present their collections on electronic media, as well as on the global network (Mandić 2008: 43). ence of the European Union (EU) ${ }^{11}$ and owing to the efforts of the National Centre for Digitization (NCD). This Centre was established in 2002 by a group of scientific and cultural institutions in Serbia, following the example of similar centres in Hungary and Bulgaria, for the sake of defining national strategies and standards, as well as coordinating the process of digitization in the field of culture in Serbia ("The Proposal to Establish National Centre for Digitization,” 2002: 3). ${ }^{12}$ Even

11 Having recognized the potential of digitization of cultural heritage in conservation, education and tourism, in 2000 the EU determined, as one of its goals, the incentive to present European digital content on the global network (European Commission 2002: 24-26). Following the meeting of European Commission representatives and members of the European Union in Lund in 2001, it drew a series of conclusions regarding digitization of European heritage ("The Lund Principles," 2001).

12 These include the following institutions: Institute of Archaeology SASA, State Archives of Serbia, Faculty of Mathematics of the University in Belgrade, Mathematical Institute SASA, National Library of Serbia, National Museum in Belgrade and Institute for the Protection of Cultural Monuments of the Republic of Serbia. 
1980

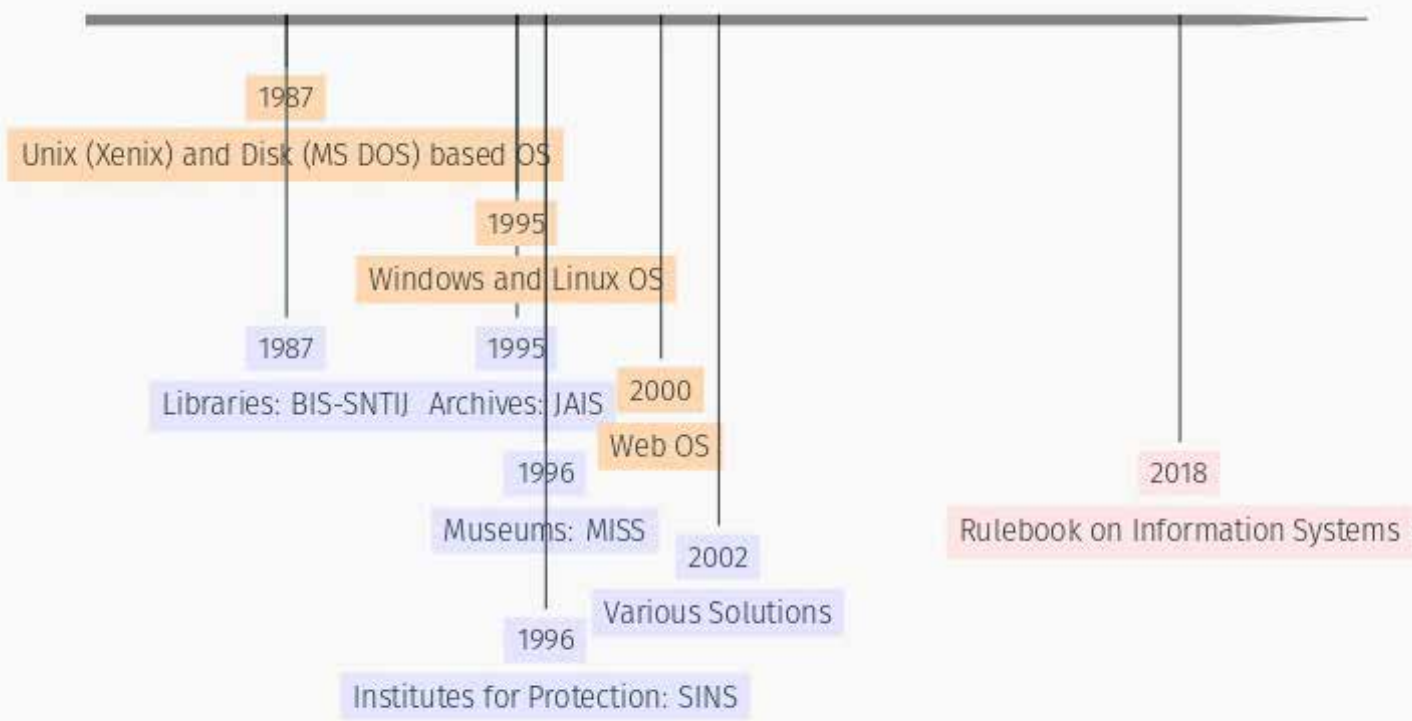

Fig. 1 Phases of information systems development within Serbian institutions for protection.

back then, it became evident that there was no equal development in the field of digitization of cultural heritage in Serbia and that it was therefore necessary to form a mechanism for encouraging and improving this process, which would be financed from the state budget (Ibid). Although the attempt to formalize the activities of the NCD failed, ${ }^{13}$ through its journal Review of the National Centre for Digitization and scientific conferences, the Centre enabled interested institutions and individuals to present results of their work and network to share knowledge and future common ven-

13 In 2002, NCD representatives submitted a proposal to the Ministry of Science and Technological Development of the Republic of Serbia and the Ministry of Culture and Information of RS on the official establishment of the National Center for Digitization ("The Proposal to Establish National Centre for Digitization," 2002). However, despite the fact that the state authorities supported and promoted this idea (Stefanović 2002: 3), in the end they were not able to formalize it: "The possibilities of this Ministry are such that we can only continue to give support for your initiative" (Despotović 2003). tures. ${ }^{14}$ However, the lack of an official national strategy in the field of culture resulted in further unequal development of the digitization process in cultural heritage institutions in Serbia. Whereas some institutions sought to integrate this process into their missions and services as soon as possible, often with the support of international initiatives (such as the EU and UNESCO support programs), others, especially in less developed areas, were unable to do so due to lack of funds, equipment and technical support. Hence, digitization was understood as a project activity rather than a regular activity (Aćimović 2016: 46). Furthermore, in the absence of official guidelines, institu-

14 For example, at the third scientific-professional meeting of the NCD held in Belgrade in 2004, the South-Eastern European Digitization Initiative (SEEDI) was launched, constituting an "open forum" consisting of experts in the field of heritage protection, information technology, humanities and basic sciences with the aim of "developing awareness about digitization of cultural and scientific heritage" primarily in thirteen SEE countries ("SEEDI - General Guidelines" 2006). 
tions that had a chance to implement new technologies in their practice have developed their own policies regarding digitization of heritage (Ibid). The consequence has been the application of different standards and systems for the description and management of cultural heritage, which has called into question the consistency and possibility of migration, preservation and availability of digitized content in the future.

When it comes to archaeology, it should be noted that a special Subcommittee on Archaeology and Monument Protection was originally intended to be opened at the NCD, which would consider the application of new technologies to archaeological methodology, as well as the importance of regulating the very application process in the field of archaeology ("The Proposal to Establish National Centre for Digitization," 2002, 6 and 9). Although this idea did not take hold in this form, it can be recognized to some extent in the activity of the Viminacium Centre for New Technologies, founded in 2003 with the task of developing and applying methods of non-destructive field research (Korać 2005: 7), ${ }^{15}$ as well as the Centre for Digital Archaeology of the Faculty of Philosophy in Belgrade $^{16}$, founded in 2004 with the task of introducing computer technologies into archaeological methodology (N.M. 2006; Tasić 2010). In addition, in 2005 the journal Archaeology and Natural Sciences was launched for the purpose of publishing results of the application of new technologies within archaeological research (Korać 2005: 7). Chart 2 attempts to identify and categorize some of the initiatives related to the process of applying digital technologies in the field of archaeology in Serbia in the period from the first known

15 This center was founded by three members of the NCD, the Institute of Archaeology SASA, Mathematical Institute SASA and the Faculty of Mathematics of the University of Belgrade, as well as the Faculty of Mining and Geology of the University of Belgrade (Serbian Business Registers Agency, 2020).

16 Also known as Innovation Center for the Implementation of Information Technologies in Archaeology and Anthropology (Tasić quoted in Tasić 2020). project in 1995 to the adoption of the new Law on Culture in 2009 (see Section 00). Based on the data in Chart 2, it is concluded that the focus was primarily on gathering interdisciplinary teams and the launch of formal organizations through which the necessary resources for development and application of new methods and technologies in the field of archaeology could be obtained. For example, multispectral scanning, infrared thermal and geo-radar non-destructive field surveys for obtaining, interpreting and storing data in digital format gained particular prominence in this period (Tasić 2007; Korać 2003; Redžić 2005; Miletić 2009). The establishment of electronic systems for managing, preserving and making available digitized and digital content likewise came to the fore. Notable instances include creating e-libraries (Ajdačić op.cit), electronic databases (Tasić 2003; Temerinski 2003; "Cultural Monuments in Serbia," op.cit) and virtual presentations (Miljković 2004b; Korać 2006a). Finally, international cooperation has been set up to exchange expertise regarding application of new methods, web databases and dynamic presentations in the field of archaeology. ${ }^{17}$ It should be highlighted that this period was still an experimental phase of applying new methods and technologies in the field of archaeology in Serbia, in which traditional research methods were still used in most cases. ${ }^{18}$

17 For example, although there was no official project, the Institute of Archaeology SASA has collaborated with the Temple University of Philadelphia since 2003 and the University of Wisconsin-Madison since 2008 in the field of data mining, when the project Viminacium already reached 100,000 artifacts for processing.

18 This can be seen according to description of research in the field of archaeology undertaken in Serbia in the period from 1995 to 2009 , whose results were published in eminent national scientific journals, such as Starinar, Glasnik Srpskog arheoloskog drustva and Zbornik Narodnog muzeja - arheologija (Recueil du musée national-archéologie). 
Chart 2 Review of some of the initiatives for the application of new methods and technologies in the field of archaeology in Serbia in the period 1995-2006.

\begin{tabular}{|c|c|c|c|}
\hline Year & Project & Organization & Topic \\
\hline 1995 & $\begin{array}{c}\text { Project PANDORA } \\
\text { (Mijajlović 2002: 12; Korać } \\
\text { 2006b: 119) }\end{array}$ & $\begin{array}{c}\text { Institute of Archaeology } \\
\text { SASA } \\
\text { Mathematical Institute }\end{array}$ & $\begin{array}{l}\text { Expert system for dating } \\
\text { archaeological material }\end{array}$ \\
\hline 1996 & $\begin{array}{l}\text { Project Viminacium } \\
\text { ("Viminacium-History of } \\
\text { Exploration," n.d.) }\end{array}$ & $\begin{array}{c}\text { Institute of Archaeology } \\
\text { SASA }\end{array}$ & $\begin{array}{l}\text { Introduction of new meth- } \\
\text { ods and technologies in ar- } \\
\text { chaeological field research }\end{array}$ \\
\hline \multirow{2}{*}{1998} & $\begin{array}{c}\text { Project Rastko } \\
\text { (Stefanović 1998) }\end{array}$ & $\begin{array}{c}\text { Project Rastko - Library } \\
\text { of Serbian Culture on the } \\
\text { Internet }\end{array}$ & $\begin{array}{c}\text { E-library of journals } \\
\text { and literature of various } \\
\text { scientific fields, including } \\
\text { archaeology }\end{array}$ \\
\hline & $\begin{array}{c}\text { Project Vinča } \\
\text { (Tasić 2014: 25-27; Ignja- } \\
\text { tović 2010: 9; Tasić 2007) }\end{array}$ & $\begin{array}{l}\text { Department of Archaeolo- } \\
\text { gy, Faculty of Philosophy } \\
\text { in Belgrade }\end{array}$ & $\begin{array}{l}\text { Introduction of computer } \\
\text { technologies in archaeolog- } \\
\quad \text { ical methodology }\end{array}$ \\
\hline 2000 & $\begin{array}{c}\text { Anarheologija } \\
\text { (Filipović 2000; Starović } \\
\text { n.d.) }\end{array}$ & $\begin{array}{l}\text { Archaeology Program at } \\
\text { Petnica Science Center }\end{array}$ & $\begin{array}{c}\text { Popular-science electron- } \\
\text { ic journal in the field of } \\
\text { Archaeology and related } \\
\text { sciences }\end{array}$ \\
\hline \multirow[b]{2}{*}{2001} & $\begin{array}{c}\text { Project Vinča - Belo Brdo } \\
\text { systematic geophysical } \\
\text { surveys } \\
\text { (Tasić 2007: 8) }\end{array}$ & $\begin{array}{l}\text { Department of Archaeolo- } \\
\text { gy, Faculty of Philosophy } \\
\text { in Belgrade }\end{array}$ & Geoelectric terrain surveys \\
\hline & \begin{tabular}{|} 
Data Base of Conditions \\
and Protective Measures of \\
Monuments Sites \\
(Temerinski 2003)
\end{tabular} & $\begin{array}{l}\text { Republic Institute for the } \\
\text { Protection of Cultural } \\
\text { Monuments }\end{array}$ & $\begin{array}{l}\text { Provides basic facts about } \\
\text { the monument, give an up } \\
\text { to date } \\
\text { history of previous pro- } \\
\text { tective activities, and } \\
\text { determine the necessary } \\
\text { conservationist measures } \\
\text { and their urgency. }\end{array}$ \\
\hline
\end{tabular}




\begin{tabular}{|c|c|c|c|}
\hline \multirow{3}{*}{2002} & $\begin{array}{c}\text { Proposal on the establish- } \\
\text { ment of the Subcommittee } \\
\text { for Archaeology and Monu- } \\
\text { ment Protection } \\
\text { ("The Proposal to Establish } \\
\text { National Centre for Digitiza- } \\
\text { tion," 2002: } 6 \text { and 9) }\end{array}$ & $\begin{array}{c}\text { National Digitization } \\
\text { Centre }\end{array}$ & $\begin{array}{l}\text { Regulation and coordi- } \\
\text { nation of the digitization } \\
\text { process in the field of } \\
\text { archaeology }\end{array}$ \\
\hline & $\begin{array}{c}\text { Project Viminacium, sys- } \\
\text { tematic geophysical surveys } \\
\text { (Korać 2003: 52) }\end{array}$ & $\begin{array}{c}\text { Institute of Archaeology } \\
\text { SASA }\end{array}$ & $\begin{array}{l}\text { Georadar, geomagnetic and } \\
\text { geoelectric terrain surveys }\end{array}$ \\
\hline & $\begin{array}{c}\text { Digitization of archaeologi- } \\
\text { cal documentation of Miloje } \\
\text { M. Vasić (1912-1934) } \\
\text { (Tasić cited in Miljković, } \\
\text { 2004a) }\end{array}$ & $\begin{array}{l}\text { Department of Archaeol- } \\
\text { ogy } \\
\text { Faculty of Philosophy, } \\
\text { University of Belgrade }\end{array}$ & $\begin{array}{l}\text { Digitization of } 870 \text { glass } \\
\text { plates (photographic } \\
\text { negatives), } 20 \text { plans on a } \\
\text { hammer paper, } 2000 \text { illus- } \\
\text { trations and } 7 \text { volumes of } \\
\text { Vasić's diaries }\end{array}$ \\
\hline \multirow{2}{*}{2003} & $\begin{array}{l}\text { Establishment of the Vi- } \\
\text { minacium Center for New } \\
\text { Technologies } \\
\text { ("Serbian Business Regis- } \\
\text { ters Agency" 2020) }\end{array}$ & $\begin{array}{l}\text { Institute of Archaeology } \\
\text { Mathematical Institute } \\
\text { Faculty of Mathematics } \\
\text { Faculty of Mining and } \\
\text { Geology }\end{array}$ & $\begin{array}{l}\text { Development and appli- } \\
\text { cation of non-destructive } \\
\text { field research methods }\end{array}$ \\
\hline & $\begin{array}{l}\text { ArheoPackPro! Project } \\
\text { (Tasić 2003) }\end{array}$ & $\begin{array}{l}\text { Department of Archaeol- } \\
\text { ogy } \\
\text { Faculty of Philosophy, } \\
\text { University of Belgrade }\end{array}$ & $\begin{array}{l}\text { Software system for input, } \\
\text { processing and interpreta- } \\
\text { tion of digital archaeologi- } \\
\text { cal documentation }\end{array}$ \\
\hline \multirow{3}{*}{2004} & $\begin{array}{c}\text { Establishment of the Centre } \\
\text { for Digital Archaeology } \\
\text { (N.M. 2006; Tasić 2010; } \\
\text { Tasić 2020) }\end{array}$ & $\begin{array}{l}\text { Department of Archaeol- } \\
\text { ogy } \\
\text { Faculty of Philosophy of } \\
\text { the University of Belgrade }\end{array}$ & $\begin{array}{c}\text { A service center that } \\
\text { connects archaeology with } \\
\text { digital technologies }\end{array}$ \\
\hline & $\begin{array}{c}\text { Project Digitization and } \\
\text { electronic presentation of } \\
\text { Medieval Serbian Monas- } \\
\text { teries } \\
\text { (Ognjanović 2005) }\end{array}$ & $\begin{array}{c}\text { National Centre for Digiti- } \\
\text { zation } \\
\text { UNESCO }\end{array}$ & $\begin{array}{c}\text { Development of electronic } \\
\text { database and web presenta- } \\
\text { tion of immovable cultural } \\
\text { property }\end{array}$ \\
\hline & $\begin{array}{c}\text { Virtual Belgrade of 15th } \\
\text { Century } \\
\text { (Miliković 2004) } \\
\end{array}$ & $\begin{array}{l}\text { Faculty of Philosophy, } \\
\text { University of Belgrade }\end{array}$ & $\begin{array}{c}\text { 3D reconstruction of } \\
\text { archaeological artifacts and } \\
\text { VR presentation } \\
\end{array}$ \\
\hline 2005 & $\begin{array}{c}\text { Journal Archaeology and } \\
\text { Natural Sciences launched } \\
\text { (Korać 2005: 7) }\end{array}$ & $\begin{array}{l}\text { Viminacium Centre for } \\
\text { New Technologies }\end{array}$ & $\begin{array}{c}\text { Publication of the results } \\
\text { of the application of new } \\
\text { technologies within the } \\
\text { framework of archaeologi- } \\
\text { cal research }\end{array}$ \\
\hline
\end{tabular}




\begin{tabular}{|c|c|c|c|}
\hline \multirow{2}{*}{2006} & $\begin{array}{c}\text { "Viminacium lumen meum" } \\
\text { interactive CD-ROM } \\
\text { (Korać 2006a; Joksimović } \\
\text { 2006) }\end{array}$ & $\begin{array}{c}\text { Viminacium Centre for } \\
\text { New Technologies } \\
\text { Institute of Archaeology } \\
\text { SASA } \\
\text { Multimediaworx }\end{array}$ & $\begin{array}{c}\text { Application of VR Pan- } \\
\text { oramas in visualisation of } \\
\text { Cultural Heritage }\end{array}$ \\
\cline { 2 - 4 } & $\begin{array}{c}\text { GPR Research in the Area } \\
\text { of Upper Town and Lower } \\
\text { Town of Belgrade Fortress } \\
\text { (Miletić 2009) }\end{array}$ & $\begin{array}{c}\text { Application of new } \\
\text { geophysical methods and } \\
\text { digital technology in the } \\
\text { development of digital } \\
\text { terrain model }\end{array}$ \\
\hline
\end{tabular}

\section{REGULATION OF THE PROCESS OF CULTURAL (ARCHAEOLOGI- CAL) HERITAGE DIGITIZATION IN SERBIA}

Taking into account that the existing digitization projects of cultural heritage in the Republic of Serbia differed in terms of applied systems and standards for description and management of heritage, including archaeological heritage, the issue of consistency in preserving and making digitized and digital content available in the future arose. Under these circumstances, back in 2006, the Ministry of Culture and Information formed an inter-sectoral working group with the task of drafting a national strategy for digitization of cultural heritage, in which representatives of the National Centre for Digitization also took part. The first strategy draft was created in August 2008. ${ }^{19}$ However, since this draft was not officially adopted at the time, Serbia failed to join European countries that were among the first to adopt national strategies regarding digitization of cultural heritage (European Commission, 2008: 17-18; European Commission, 2014: 10). Apparently, this draft was premature and did not correspond to the actual situation in Serbia, because not until the adoption

19 This information was provided through conversation with Professor Zoran Ognjanović, Head of the Mathematical Institute SASA, who participated in compiling the aforementioned draft strategy ("Draft of the National Strategy for Cultural Heritage Digitization for the 2008-2015 period," 2008). of the Law on Culture in 2009, did the inclusion of digitization process into the agenda of cultural heritage institutions become mandatory. For this reason, they could not contribute to creating and improving a unique information system in the field of cultural heritage protection (Ognjanović 2019). The 2009 law has therefore provided a legal basis for integration of the digitization process into the missions and services of cultural heritage institutions. Although digitization of cultural heritage in Serbia was not grounded in strategic documents before 2009, some institutions of national importance carried out the digitization process even before that period (Ognjanović 2019).

The Law on Culture, adopted in 2009 and amended in 2011, has influenced the process of cultural heritage digitization to be further recognized through distribution of budget funds. Thus, in the period 2013-2017, the Ministry of Culture and Information co-financed and financed several digitization projects in the field of cultural heritage. When it comes to archaeological heritage, these included projects aimed at purchasing digitization equipment, digitization of archaeological collections and documentation, 3D laser scanning and development of information systems, such as those for field archaeological documentation. As leaders of the projects under consideration, one finds not just cultural heritage institutions (i.e., institutes for the protection of cultural heritage and cultural heritage museums), but also educational and scientific institutions (Faculty of Philoso- 
phy of the University of Belgrade and Institute of Archaeology SASA), as well as civil society organizations (Centre for Urban Development) (Ministry of Culture and Information of the RS, 2013-2017).

Notwithstanding the fact that since 2013 considerable funds have been invested in digitization in the field of culture, there is still no clear national strategy or transparent records of how many state funded digitization projects were actually implemented. Hence, the Ministry of Culture and Information, inspired by the efforts of the EU (Masliković quoted in Tanjug, 2019), presented several strategic initiatives and documents in order to determine further direction of digital transformation process in the field of culture. ${ }^{20}$ It likewise established the Sector for Digitization of Cultural Heritage and Contemporary Creativity as a mechanism for coordination and organizing that process. (Ministry of Culture and Information, May 2019). Particularly noteworthy is the adoption of the Rulebook on Detailed Conditions for the Digitization of Cultural Heritage, since it is the first bylaw in Serbia regulating the process of digitization in the field of culture. This act obliges cultural heritage institutions to determine the digitization program within their annual action plan and to digitize the entire cultural heritage in the period of five years, with the exception of archives, as well as to establish information system determined by the very act (Службени гласник PC, 76/2018). Therefore, it also obliges institutions responsible for preservation and protection of archaeological heritage

20 These include, inter alia, the draft Strategy for Cultural Development in Serbia in the period from 2017 to 2027 and the accompanying action plan in which the digitization of cultural heritage is defined as one of the five areas of cultural development in Serbia with the general goal of preserving digitized content and ensuring its accessibility, exchange and presentation (Ministry of Culture and Information, May 2017). These also include Guidelines for the digitization of cultural heritage that provided specific guidelines for implementation of the digitization process in cultural heritage institutions (Ministry of Culture and Information, September 2017). to implement the information system required by law and to send the data entered into that system not only to the state data centre for management and permanent storage ("Law on Electronic Governance," 2018; Vulikić 2019), but also to the national aggregator / search engine of cultural heritage in order to be publicly available ("The Cultural Heritage Browser," 2019). In practice, this meant overcoming several challenges, including the adoption of the prescribed system, regardless of whether another (maybe better?) ${ }^{21}$ system had already been used for managing archaeological and other cultural heritage. Furthermore, it included finding solutions on how to make data open and publicly available, yet protect them and respect privacy in accordance with the Law on Protection of Personal Data ("Law on Protection of Personal Data," 2018). Last but not least, although the ultimate goal was to move to a single information system, no single solution for archaeological heritage has been offered. For example, the abovementioned Rulebook obliges institutes for protection of cultural heritage to implement a system with a locally developed standard for description of archaeological heritage managed by the Republic Institute for the Protection of Cultural Monuments (Lajbenšperger 2019), whereas museums use a system based on the Museum Documentation Association / Spectrum standard, coordinated by the Historical Museum of Serbia (Vulikić 2019). Therefore, the assumption is that archaeological heritage will be described following at least two different standards in the future, that it will be stored within different systems, and that the duplication of content is likely to be expected.

21 During unofficial conversation with curators of the Ethnographic Museum in Belgrade, it was repeatedly claimed that the system developed in this institution is of better quality than the system prescribed by law. However, as the director of the National Museum once remarked, "although earlier solutions were satisfactory, they failed in implementation (Borić Brešković quoted in "Beginning of the Project - Implementation of the Uniform Information System in Serbia," 2018). 
The backbone of the entire initiative of the Ministry of Culture and Information is "to introduce additional order, technology and the best experts in a pretty chaotically initiated digitization process" (Vukosavljević quoted in Blic, August 2017), as well as to obtain "clear instructions" on how "to preserve cultural heritage in digital form and make it accessible to citizens via one click" (Vukosavljević quoted in Novosti Online, October 2018). In principle, this initiative of the official authorities was positively assessed and part of the institutions of national importance publicly shared the selected material with the most basic data within the national search engine. They included thirteen institutes for the protection of cultural monuments and over fifty museums ("The Cultural Heritage Browser," 2019). However, there is the everpresent criticism regarding the process of cultural heritage digitization, claiming that it is not adequately and precisely defined, that this process is not the only way to preserve and protect cultural heritage and that cultural heritage originally created in digital form is not taken into consideration (Blic, September 2017; Ministry of Culture and Information of the RS, October 2017). When it comes to digitization of archaeological heritage, there is a proposal to provide earmarked funds "for digital archiving of key documents from the history of Serbian archaeology, providing funds for storage and preservation of archival material on archaeology and archaeological documentation" (Ministry of Culture and Information of the RS, October 2017: 3). Since these are recently adopted norms and tools, it remains to be seen whether these measures will contribute to the expected and more systematic and productive process of archaeological heritage digitization.

Certain contribution to the abovementioned issue will be given through the participation of two institutes, Institute of Archaeology and Mathematical Institute SASA, in the international COST project CA-18128, entitled SEADDA (Saving European Archaeology from the Digital Dark Age) (SEADDA 2019). Both of these institutes are represented in the abovementioned project by the authors of this paper.

The SEADDA project was adopted in 2018 and it became operational in 2019. Nominally, project participants can be involved in one of the four working groups, although they are often active in several. The first working group, the socalled Stewardship of Archaeological Data deals with legal issues related to legitimacy of storage and disposal of archaeological data. The second working group Planning for Archiving builds on the previous one and deals with the issue of storing data over a long period of time and their availability due to advances in technology. The third working group focuses on finding and studying examples of the so-called best practices, which have proven to be the most efficient and successful among fellow archaeologists in Europe. This working group is entitled Preservation and Dissemination Best Practice. Finally, the fourth working group, entitled Use and Re-Use of Archaeological Data, deals with finding out how to adapt archived data most effectively so that it can be usable now and in the future.

\section{CONCLUSION}

The overview of cultural heritage digitization in the Republic of Serbia given in this paper reveals that ever since the late 1980-ties, there have been various attempts to digitize parts of Serbia's cultural heritage. During the last decade of the 20th century, there were many efforts in digitizing both artefacts kept as various museums (their images and IDs) or data gained during specific archaeological excavations. For a long time, cultural heritage digitization was regarded as a converting process of analogue contents into their digital form exclusively. Among the earliest efforts, there was the PANDORA project (1995-1996), implemented at the Institute of Archaeology SASA and the Mathematical Institute SASA. Its goal was to create a prototype of an expert system for dating 
archaeological material based on digitization of available archaeological sources. However, all of those attempts were conducted as isolated cases and they depended on the equipment each and every cultural heritage institution possessed at that specific moment.

During the period between 2000 and 2018, upgrading of the existing solutions and developing new ones took place. In that period, owing to the efforts of the National Centre for Digitization (NCD) and under the influence of the EU, the term and concept of cultural heritage digitization have entered into wider usage in Serbia.

In recent years, digitization of cultural heritage has become an imperative for all of the institutions that deal with it. This is why there are attempts to establish a strategy at the national level and implement it throughout the country. There are efforts of the Serbian Ministry of Culture and Information to regulate processes of digitizing cultural heritage and digital transformation of the protecting institutions. The new regulation on documenting archaeological research prescribes that documenting should be conducted electronically, within a unique information system for keeping incorporated archaeological documentation that should be secured by the Ministry of Culture and Information.

It should be mentioned that there is a permanent question of accessibility, due to the fear of misuse of digitized data. Although many institutions tend to keep their digitized data only to themselves or to a narrow circle of experts, initiative of the official authorities was positively assessed and part of the institutions of national importance publicly shared the selected material within the national search engine. Of course, in the future, this question needs to be clarified and very precisely defined, enabling the public and experts to get insight into the digital database but still preventing misuse.

On the other hand, in many cultural heritage institutions of national importance, a tendency was observed of "over-digitizing" their data. For example, dozens of photographs are made of a single artefact, although it does not possess an extraordinary value. 3D images of various objects are designed, although again, many of the objects are simply duplicates.

A step forward will surely be made with many of the international projects currently taking place and with several of our experts taking part in those projects. One of them is the COST Action 18128. It deals with European archaeology as a target to be digitized, but it keeps focus on the questions how, why and when something needs to be digitized.

The authors of this paper hope that in the future, possibly already in 2023, at the end of the abovementioned COST Action 18128, a clear picture would emerge, supporting digitization of cultural heritage, but keeping it within reasonable limits and by doing that - also making it accessible to a broad public.

\section{BIBLIOGRAPHY}

\section{Аћимовић, М. 2016}

Анкета о доступности фото-документације музеја у Србији. У: Отворени приступ музејској документацији у Србији: искуства, изазови u потенцијали, М. Стијовић (изд.), Београд: Централни институт за конзервацију: 43 - 52. (Aćimović, M. 2016

Anketa o dostupnosti foto-dokumentacije muzeja u Srbiji. U: Otvoreni pristup muzejskoj dokumentaciji u Srbiji: iskusta, izazovi i potencijali, M. Stijović (izd.), Beograd: Centralni institut za konzervaciju: 43 - 52).

\section{Andre, Q.J.P. 1989}

Optical Disc Applications in Libraries. Library Trends 37 (3): 326 - 342.

\section{Anon. 2019,}

Обједињени портал за претрагу културног наслеђа Србије, Novosti, 26. мај.

(Anon. 2019, Objedinjeni portal za pretragu kul- 
turnog nasleđa Srbije, Novosti, 26. maj).

https://www.novosti.rs/вести/култура.487.ht-

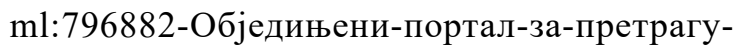
културног-наслеђа-Србије (accessed October 2nd, 2020)).

\section{Anon. 2018, Вукосављевић:}

Културно наслеђе Србије биће доступно грађанима на један клик. Новости, 3. октобар. (Anon. 2018, Vukosavljević: Kulturno nasleđe Srbije biće dostupno građanima na jedan klik". Novosti, 3. oktobar).

http://www.novosti.rs/vesti/kultura.71.htm1:752853-Vukosavljevic-Kulturno-nasledje-Srbije-bice-dostupno-gradjanima-na-jedan-klik (accessed April 16th, 2020).

\section{Anon. 2017a,}

Pohvale i kritike za Predlog strategije razvoja kulture. Blic, 4. septembar.

https://www.blic.rs/kultura/vesti/pohvale-i-kritike-za-predlog-strategije-razvoja-kulture/2vw91we (accessed October 2nd, 2020).

\section{Anon 2017b,}

Potpisan Sporazum o digitalizaciji kulturnog nasleđa. Blic, 1. avgust.

https://www.blic.rs/kultura/vesti/potpisan-sporazum-o-digitalizaciji-kulturnog-nasleda/2h8ybcp (accessed October 2nd, 2020).

Почетак пројекта - Имплементације јединственог информационог система у музејима у Сpбији.

Početak projekta - Implementacije jedinstvenog informacionog sistema u muzejima u Srbiji.

http://imus.org.rs/pocetak-projekta-implementacije/ (accessed August 26th, 2020)).

\section{Bešlin, M. 2003}

Digitalizacija arhivske građe u Istorijskom arhivu u Novom Sadu: neka iskustva i preporuke. Review of the National Center for Digitization 3: 66 - 72.

\section{Бојковић, С. 2016}

Музејска документација - дигитализација и доступност - на примеру Историјског музеја Србије. У: Отворени приступ музејској документацији у Србији: искуства, изазови и потениијали, М. Стијовић (изд.), Београд: Централни институт за конзервацију: $52-61$.

(Bojković, S. 2016

Muzejska dokumentacija - digitalizacija i dostupnost - na primeru Istorijskog muzeja Srbije. U: Otvoreni pristup muzejskoj dokumentaciji u Srbiji, iskustva, izazovi i potencijali, M. Stijović (izd.), Beograd: Centralni institut za konzervaciju: $52-61)$.

Централни регистар арехеолошких налазишта. (Centralni registar arheoloških nalazišta. http://www.heritage.gov.rs/cirilica/Download/ AN.xls (accessed September 14th, 2020).

\section{COBISS Platform. 2016.}

https://www.cobiss.net/sr/platforma-cobiss.htm (accessed September 28th, 2020).

\section{COBISS.Net in numbers. 2019.}

https://www.cobiss.net/doc/Statistike_2019_eng. pdf (accessed September 28th, 2020).

\section{Cohen, D. and Rosenzweig, R. 2005}

Digital History A Guide to Gathering, Preserving, and Presenting the Past on the Web. University of Pennsylvania Press.

http://chnm.gmu.edu/digitalhistory/ (accessed October 2nd, 2020).

\section{Crnobrnja, A. 2019}

Kradljivci prošlosti. Vreme, 28. novembar. https://www.vreme.com/cms/view. php?id=1734987 (accessed September 14th, 2020).

\section{Црвчанин, М. 1983}

Тезаурус за ликовне уметности -методологија израде. Београд - Народна библиотека Србије. 
(Crvčanin, M. 1983

Tezaurus za likovne umetnosti - metodologija izrade. Beograd - Narodna biblioteka Srbije).

\section{Cvetković, S. 2013}

Razvoj arhivske službe u Srbiji u drugoj polovini 20. veka. Atlant 23 (1): 215 - 234.

\section{Културни споменици у Србији (n.d.).}

Kulturni spomenici u Srbiji.

http://spomenicikulture.mi.sanu.ac.rs/ (accessed September 29th, 2020).

\section{Деспотовић, J. 2003}

Допис Јована Деспотовића, помоћника Министра за културу и јавно информисање, др Зорану Богдановићу, председнику Одбора за оснивање Националног центра за дигитализацију, 21. фебруара (необјављено). Архив Математичког института САНУ.

(Despotović, J. 2003

Dopis Jovana Despotovića, pomoćnika Ministra za kulturu i javno informisanje dr Zoranu Bogdanoviću, predsedniku Odbora za osnivanje Nacionalnog centra za digitalizaciju, 21. februara (neobjavljeno). Arhiv Matematičkog instituta SANU.

\section{Drača Muntean, A. 2020}

Serbia: National Policy Report. Herein Network. Available online https://www.coe.int/en/web/ herein-system/serbia (accessed October 12th, 2020).

Предлог Националне стратегије за дигитализацију културног наслеђа у периоду од 2008. до 2015. године. 2008. (необјављено). Архив Математичког института САНУ.

Predlog nacionalne strategije za digitalizaciju kulturnog nasleđa u periodu od 2008. do 2015. godine (neobjavljeno). Arhiv Matematičkog instituta SANU.
Dragićević-Šešić, M., Tomka, M. and Mikić, $H$. 2018

Country Profile Serbia. In Association of the Compendium of Cultural Policies and Trends, "Compendium of Cultural Policies and Trends," 19th edition 2018.

https://www.culturalpolicies.net/wp-content/ uploads/pdf_full/serbia/serbia_092018.pdf (accessed September 23rd 2020).

European Commission. 2014, Cultural heritage Digitisation, online accessibility and digital preservation. REPORT on the Implementation of Commission Recommendation 2011/711/EU 2011-2013.

http://ec.europa.eu/newsroom/dae/document. cfm?doc_id=9745 (accessed October 2nd, 2020).

European Commission. 2008, Commission Staff Working Document accompanying the Communication from the Commission to the Council, the European Parliament, the European Economic and Social Committee and the Committee of the Regions. Europe's cultural heritage at the click of a mouse. Progress on the digitisation and online accessibility of cultural material and digital preservation across the EU.

https://eur-lex.europa.eu/legal-con-

tent/EN/TXT/PDF/?uri=CELEX-

:52008SC2372\&qid $=1548246641969 \&$ from $=\mathrm{EN}$

(accessed October 2nd, 2020).

European Commission. 2002, eEurope 2002. An Information Society for All. Draft Action Plan prepared by the European Commission for the European Council in Feira 19-20 June 2000. https://eur-lex.europa.eu/legal-content/ EN/TXT/PDF/?uri=CELEX:52000DC0330\&qid $=1548246761698 \&$ from $=E N(a c-$ cessed October 2nd, 2020). 


\section{Filipović, V. 2000}

Anarheologia, Svet kompjutera, oktobar. https://www.sk.rs/2000/10/skin03.html (accessed September 30th, 2020).

\section{Gavrilović, G. 2015}

The Eternitas Web Application - Implementation Step of the Museum Information System of Serbia. Review of the National Centre for Digitization 27: $1-12$.

\section{Hughes, L. M. 2004}

Digitizing Collections Strategic issues for the information manager. New Baskerville: Zurich: Facet Publishing.

\section{Игњатовић, М. 2010}

Винча - наслеђе за будућност. У: Винча: фрагменти за реконструкиију прошлости, М. Игњатовић (изд.), Београд: Музеј града Београда: 8-13.

(Ignjatović, M. 2010

Vinča - nasleđe za budućnost. U: Vinča: fragmenti za rekonstrukciju prošlosti, M. Ignjatović (izd.), Beograd: Muzej grada Beograda: 8 - 13).

Immovable Cultural Property - IMP. (n.d.). http://www.heritage.gov.rs/english/nepokretna kulturna_dobra.php (accessed September 14th, 2020).

\section{Joksimović, G. 2006}

Viminacium Lumen Meum, Svet kompjutera, Maj.

https://www.sk.rs/2006/05/skcd05.html (accessed September 30th, 2020).

\section{Korać, M., Marković, S. i Obradović, J. 2006a}

Primena VR panorama u vizuelizaciji kulturnog nasleđa na interaktivnom CD ROM-u "Viminacium Lumen Meum". Arheologija i prirodne nauke 2: $97-104$.
Korać, M., Ognjanović Z. i Dugandžić, F. 2006b PANDORA - Ekspertni sistem za datiranje iskopina. Arheologija i prirodne nauke 2: 105 - 120.

\section{Korać, M. 2005}

Reč urednika. Arheologija i prirodne nauke 1: 7.

\section{Korać, M. i Miletić, V. 2003}

Primena georadara $\mathrm{u}$ arheologiji. Review of the National Center for Digitization 2: 52 - 56.

Korać, M. 1999

SUPERBASE za arheologe. Požarevac: Narodni muzej u Požarevcu.

\section{Korać, M. 1994}

Model arheološke baze podataka. Beograd: Arheološki institut.

\section{Korać, M. 1991a}

AGORA BBS. Multikorisnički Online Bulletin Board System društvenih i humanističkih nauka. U Računari u društvenim i humanističkim nauka$m a$, D. Obradović i D. Prlja (izd.), Zemun: Arheološki institut: 31 - 41 .

\section{Korać, M. 1991b}

Informacioni sistemi u arheologiji (ISA). U Zbornik radova II naučnog skupa o sistemu naučnih i tehnoloških informacija, Beograd: SIT Jugoslavije: 287-292.

\section{Kosanović, B. i Šipka, P. 1996}

SocioFakt - jugoslovenska baza za društvene činjeničke nauke. Merenje u psihologiji 2: 85 - 95.

\section{Lajbenšperger, N. 2019}

Information System of Immovable Cultural Property. Presentation at The Seventeenth National Conference Digitization of Cultural Heritage, Old Records from the Natural and Social Sciences and Digital Humanities, September 17th, Belgrade. 
Закон о потврђивању Европске конвенције о заштити археолошког наслеђа (ревидирана). Службени гласник, 42/2009.

Zakon o potvrđivanju Evropske konvencije o zaštiti arheološkog nasleđa (revidirana). Službeni glasnik 42/2009.

http://demo.paragraf.rs/demo/combined/Old/t/ t2009_06/t06_0142.htm (accessed September 14th, 2020).

Закон о културним добрима. Службени гласник, 71/1994.

Zakon o kulturnim dobrima. Službeni glasnik 71/1994.

https://www.paragraf.rs/propisi/zakon_o_kulturnim_dobrima.html (accessed September 11th, 2020).

Закон о заштити података о личности. Службени гласник, 87/2018.

Zakon o zaštiti podataka o ličnosti. Službeni glasnik, 87/2018.

https://www.pravno-informacioni-istem.rs/ SlGlasnikPortal/eli/rep/sgrs/skupstina/zakon/2018/87/13/reg

(accessed October 2nd, 2020).

Закон о електронској управи. Службени гласник, 27/2018.

Zakon o elektronskoj upravi. Službeni glasnik, 27/2018.

https://www.pravno-informacioni-sistem.rs/ SlGlasnikPortal/eli/rep/sgrs/skupstina/zakon/2018/27/4/reg (accessed October 2nd, 2020).

Закон о култури. Службени гласник, 72/2009. Zakon o kulturi. Službeni glasnik, 72/2009. https://www.pravno-informacioni-sistem.rs/ SlGlasnikPortal/eli/rep/sgrs/skupstina/zakon/2009/72/1/reg (accessed October 2nd, 2020).

Lazarević, B. et al. 1996

Formiranje $i$ pretraživanje baza podataka $u$ sistemu naučnih i tehnoloških informacija Srbije.
Beograd: Ministarstvo za nauku i tehnologiju Republike Srbije.

Библиотеке у систему БИСИС. (n.d.).

Biblioteke u sistemu BISIS (n.d.).

https://www.bisis.rs/biblioteke.html (accessed September 25th, 2020).

\section{Mandić, S. 2008}

Kompjuterizacija $i$ istoriografija: 1995 - 2005.

Beograd: Istorijski arhiv Beograda.

Mannoni, B. 1996

Bringing Museums Online. Commun. ACM 39: 100-105.

Manžuch, Z., Huvila, I. and Aparac-Jelušić, T. 2005

Digitization of Cultural Heritage. In: European Curriculum Reflections on Library and Information Science Education, L. Kajberg and L. Lørring (izd.), Copenhagen: The Royal School of Library and Information Science: 37-65.

\section{Maroević, I. 1993}

Uvod u muzeologiju. Zagreb: Zavod za informacijske studije Odsjeka za informacijske znanosti Filozofskog fakulteta Sveučilišta u Zagrebu.

\section{Мицић, Ј. 2019}

(изд.) Наука y покрету: Дигитализащија културног наслеђа. Радио телевизија Србије.

(Micić, J. 2019

(izd.) 2019, Nauka u pokretu: Digitalizacija kulturnog nasleđa. Radio Televizija Srbije. https:// www.youtube.com/watch?v=lxz252bRTe8 (accessed October 2nd, 2020).

\section{Мијајловић, М. и Новаковић, Ж. 2002}

Дигитализација музејских збирки Музеја града Београда. Review of the National Center for Digitization 1: 43 - 47.

(Mijajlović, M. and Novaković, Ž. 2002

Digitalizacija muzejskih zbirki Muzeja grada 
Beograda. Review of the National Center for Digitization 1: 43 - 47).

\section{Mijajlović, Ž. 2002}

$\mathrm{O}$ nekim poduhvatima $\mathrm{u}$ oblasti digitalizacije $\mathrm{u}$ poslednjoj deceniji. Review of the National Center for Digitization 1: 12 - 27.

\section{Miletić, V. i Miletić, J. 2009}

Pregled georadarskih istraživanja Gornjeg i Donjeg grada Beogradske tvrđave. Arheologija $i$ prirodne nauke 4: 37 - 39.

\section{Miljković, I. 2004a}

Računari u arheologiji: Iskopine pikselima, Svet kompjutera, 1. april.

https://www.sk.rs/arhiva/clanak/3015/racunari-u-arheologiji-iskopine-pikselima (accessed September 28th, 2020).

\section{Miljković, I. 2004b}

Kalemegdan, 3D, Svet kompjutera, May. https://www.sk.rs/2004/05/skn101.html (accessed September 30th, 2020).

Министарство културе и информисања РС. Конкурси 2013 - 2017.

Ministarstvo kulture i informisanja RS. Konkusri 2013 - 2017.

http://www.kultura.gov.rs/lat/konkursi (accessed April 10th, 2020).

Министарство културе и информисања $P C$. 2020, Реаговање Министарства културе и информисања на текст под насловом ,Миомир Кораћ, Суперархеолог”, 28. август.

(Ministarstvo kulture i informisanja RS. 2020, Reagovanje Ministarstva kultur i informisanja na tekst pod naslovom "Miomir Korać, Superarheolog", 28. avgust.

https://www.kultura.gov.rs/vest/3973/reagovanje-ministarstva-kulture-i-informisanja-na-tekst-pod-naslovom-miomir-korac-superarheolog.php (accessed September 23rd, 2020).
Министарство културе и информисања РС. 2019, Правилник о унутрашњем уређењу $и$ систематизацији радних места у Министарству културе и информисања, мај.

Ministarstvo kulture i informisanja RS. 2019, Pravilnik o unutrašnjem uređenju i sistematizaciji radnih mesta u ministarstvu kulutr i informisanja, maj.

http://www.kultura.gov.rs/docs/dokumenti/pravilnik-o-sistematizaciji-2013/pravilnik-o-unutrasnjem-uredjenju-i-sistematizaciji-radnih-mesta-u-ministarstvu-kulture-i-informisanja.docx (accessed April 10th, 2020).

Министарство културе и информисања РC. 2017, Извештај са јавне расправе о предлогу Стратегије развоја културе Републике Србије од 2017. до 2027, октобар.

(Ministarstvo kulture i informisanja RS. 2017, Izveštaj sa javne rasprave o predlogu Strategije razvoja kulutre Republike Srbije od 2017. do 2027. Oktobar.

http://www.kultura.gov.rs/docs/dokumenti/javnarasprava-o-predlogu-strategije-razvoja-kulturerepublike-srbije-od-2017--do-2027-/--izvestaj-sajavne-rasprave-o-predlogu-strategije-razvoja-kulture-republike-srbije-od-2017--do-2027-.docx (accessed April 16th, 2020).

Министарство културе и информисања РС. 2017, Смернице за дигитализаиију културног наслеђа у Републици Србији.

Ministarstvo kulture i informisanja RS. 2017, Smernice za digitalizaciju kulturnog nasleđa $u$ Republici Srbiji.

http://www.kultura.gov.rs/cyr/dokumenti/propisi-iz-oblasti-kulture/smernice-za-digitalizaciju-kulturnog-nasledja-u-republici-srbiji (accessed April 17th, 2019).

Министарство културе и информисања РC. 2017, Наирт Стратегије развоја културе Републике Србије од 2017. до 2027, мај. (Ministry of Culture and Information of the RS. 
2017, Draft of the Strategy for Cultural Development in the Republic of Serbia for the 2017-2027 Period, May. Available online http://www.kultura. gov.rs/docs/dokumenti/nacrt-strategije-razvojakulture-republike-srbije-od-2017--do-2027-/-nacrt-strategije-razvoja-kulture-republike-srbije-od2017--do-2027-.pdf (accessed April 10th, 2020).

N.M. 2006, Uspesi centra za digitalnu arheologiju. Danas, 8. februar, 4.

http://web.arhiv.rs/develop/vesti.nsf/feaee $540 \mathrm{dc} 011162 \mathrm{c} 1256 \mathrm{e} 7 \mathrm{~d} 0032 \mathrm{cb} 98 / 9 \mathrm{e}-$ 59827130695de6c12571bd007f4d19?OpenDocument (accessed September 29th, 2020).

Network of Institutes in Serbia. (n.d.)

http://www.heritage.gov.rs/english/mreza_zavoda_u_srbiji.php (accessed September 15th, 2020).

\section{Ognjanović, Z. et al. 2019}

Cultural Heritage Digitization in Serbia: Standards, Policies, and Case Studies. Sustainability 11(14). doi:10.3390/su11143788.

\section{Ognjanović, Z. 2005}

(Ed.) Electronic catalogue of cultural monuments in Serbia. Funded by UNESCO, Participation Programme 2004-2005 (grant no. 27243305 YUG). http://spomenicikulture.mi.sanu.ac.rs (accessed September 29th, 2020).

\section{Ognjanović, Z. 2002}

Nacionalni centar za digitalizaciju. Review of the National Centre for Digitization 1: 3 - 11.

\section{Пејин, J. 2002}

Први корак ка дигитализацији у Архиву Србије. Review of the National Centre for Digitization 1: $76-78$.

(Pejin, J. 2002

Prvi korak ka digitalizaciji u Arhivu Srbije. Review of the National Centre for Digitization 1: 76 $-78)$.

\section{Петровић, J. 2002}

Библиотека града Београда. Гласник Народне библиотеке Србије 4 (1): 185-202.

(Petrović, J. 2002

Biblioteka grada Beograda. Glasnik Narodne biblioteke Srbije 4 (1): 185 - 202).

\section{Redžić, S., Raičković, A. i Miletić, V. 2005}

Arheološka istraživanja lokaliteta Stig na osnovu georadarskih ispitivanja. Arheologija $i$ prirodne nauke 1: 47 - 56.

Формулар за подношење захтева за издавање одобрења за археолошка ископавања и истраживања, 2020.

Formular za podnošenje zahteva za izdavanje odobrenja za arheološka iskopavanja i istraživanja. 2020. https://www.kultura.gov.rs/tekst/86/izdavanje-dozvola-za-vrsenje-arheoloskih-iskopavanja-i-istrazivanja.php (accessed October 12th, 2020).

Правилник о ближим условима за дигитализацију културног наслеђа. Службени гласник РC, 76/2018.

Pravilnik o bližim uslovima za digitalizaciju kulturnog nasleđa. Službeni glasnik RS, 76/2018.

https://www.pravno-informacioni-sistem.rs/S1GlasnikPortal/eli/rep/sgrs/ministarstva/pravilnik/2018/76/2/reg (accessed October 2nd, 2020).

Правилник о обрасцима за документацију која се води о археолошком ископавању и истраживању. Службени гласник РC, 102/2006.

Pravilnik o obrascima za dokumentaciju koja se vodi o arheološkom iskopavanju i istraživanju. Službeni glasnik RS, 102/2006.

https://www.pravno-informacioni-sistem.rs/S1GlasnikPortal/eli/rep/sgrs/ministarstva/pravilnik/1995/19/1 (accessed September 23rd, 2020).

Правилник о обрасцима, садржају и начину вођења дневника радова и друге документације која се води о археолошким ископавањи- 
ма и истраживањима. Службени гласник РС, 67/2020.

Pravilnik o obrascima, sadržaju i načinu vođenja dnevnika radova i druge dokumentacije koja se vodi o arheološkim iskopavanjima i istraživanjima. Službeni glasnik RS, 67/2020.

https://www.pravno-informacioni-sistem.rs/S1GlasnikPortal/eli/rep/sgrs/ministarstva/pravilnik/2020/67/1/reg (accessed September 23rd, 2020).

SEADDA - Saving European Archaeology from the Digital Dark Age. (n.d.). Available online https://www.seadda.eu/ (accessed August 26th, 2020).

SEEDI - General Guidelines. (n.d.). Available online http://seedi.ncd.org.rs/documents/proposalStatute.pdf (accessed October 2nd, 2020).

Serbian Business Registers Agency [Database]. Available online https://www.apr.gov.rs/ (accessed October 2nd, 2020).

Starović, A. (n.d.). Anarheologija. Available online

http://almanah.petnica.rs/18/10.html (accessed September 30th, 2020).

\section{Стефановић, Д. 2002}

Национални центар за дигитализацију:

Умрежавање баштине. Просветни преглед 2156,19 . јуна, 3.

(Stefanović, D. 2002

Nacionalni centar za digitalizaciju: Umrežavanje baštine. Prosvetni pregled 2156, 19. juna, 3).

\section{Стефановић, 3. 1998}

Пројекат Растко - Електронска библиотека српске културе.

(Stefanović, Z. 1998

Projekat Rastko - Elektronska biblioteka srpske kulture. https://www.rastko.rs/o/index_c.html (accessed September 30th, 2020).

\section{Tasić, N. 2020}

Vinčansko društvo bilo je zasnovano na jednakosti. Danas, 6. avgust.

https://www.danas.rs/drustvo/vincansko-drustvo-bilo-je-zasnovano-na-jednakosti/ (accessed September 29th, 2020).

\section{Tasić, N. and Ignjatović, M. 2014}

Neolithic Metropolis on the River Danube - Vinča - A Guide through the Archaeological Site of Vinča. Belgrade: Belgrade City Museum.

\section{Тасић, Н. 2010}

Археолошка ископавања као метод заштите. У: Винча - фрагменти за реконструкцију прошлости, М. Игњатовић (изд.), Београд: Музеј града Београда: 14 - 19.

(Tasić, N. 2010

Arheološka iskopavanja kao metod zaštite. U: Vinča - fragmenti za rekonstrukciju prošlosti, M. Ignjatović (izd.), Beograd: Muzej grada Beograda: 14 - 19.)

Tasić, N., Vukadinović, M. i Kapuran, A. 2007 Komparativna arheološka i geofizička ispitivanja na lokalitetu Vinča-Belo Brdo metodom geoelektričnog skeniranja, Arheologija i prirodne nauke 3: 7-18.

\section{Tasić, N. i Jevremović, V. 2003}

Arheopackpro!, Programski sistem za unos, obradu i interpretaciju digitalne arheološke dokumentacije, Review of the National Center for Digitization 3: 54 - 58.

\section{Темерински, С. 2003}

База података стања и мера заштите непокретних културних добара као могућност егзактног планирања, Review of the National Center for Digitization 3: 59 - 61.

(Temerinski, S. 2003

Baza podataka stanja i mera zaštite nepokretnih kulturnih dobara kao mogućnost egzaktnog planiranja, Review of the National Center for Digitization 3: 59-61). 


\section{Темерински, С. 2002}

Кратка историја примене метода информатичких технологија у Републичком заводу за заштиту споменика културе, Review of the National Center for Digitization 1: 51 - 55.

(Temerinski, S. 2002

Kratka istorija primene metoda informatičkih tehnologija u Republičkom zavodu za zaštitu spomenika kulutre, Review of the National Center for Digitization 1: 51 -55).

Тртовац, А. 2017

Аутоматизација библиотека у Србији Историјски преглед, Библиотека 2: 101 - 114. (Trtovac, A. 2017

Automatizacija biblioteka u Srbiji - Istorijski pregled, Biblioteka 2: 101 - 114.)

The Cultural Heritage Browser. Available online https://culture.rs/ (accessed April 10th, 2020).

The Lund Principles: Conclusion of Experts Meeting, Lund, Sweden. Available online https://www. iccu.sbn.it/export/sites/iccu/documenti/lund_ principles-en.pdf (accessed April 10th, 2020).

Предлог Министарству за науку, технологију и развој РС о оснивању Националног центра за дигитализацију. 2002 (необјављено). Архив Математичког института САНУ.

Predlog Ministarstvu za nauku, tehnologiju i razvoj RS o osnivanju Nacionalnog centra za digitalizaciju. 2002. (neobjavljeno). Arhiv Matematičkog instituta SANU.

Sistem naučnih i tehnoloških informacija Jugoslavije: studija izvodljivosti. 1988. Beograd: Savez inženjera i tehničara Jugoslavije.

Viminacium - History of Exploration. (n.d.). Available online http://viminacium.org.rs/en/viminacium/istorijat-istrazivanja/\# (accessed September 28th, 2020).
Vulikić, N. 2019

Use of information and communication technology in cultural institutions. Prezentacija na konferenciji "Ethnographic Museology and Implementation of Information Technology Conference", 10. oktobar, Mala Remeta (Srbija).

\section{Vulikić, N. 2018}

Digitization has arrived in Museums (Institutes for Protection of Cultural Heritage and Archives). https://prezi.com/vwh8ycgo91j6/presentation/ (accessed September 28th, 2020).

\section{REZIME \\ SRPSKA ARHEOLOGIJA U DIGITALNOM DOBU - TRENUTNO STANJE}

\section{KLJUČNE REČI: ARHEOLOGIJA, SRBIJA, DI- GITIZACIJA, PODACI, ARTEFAKTI, PREGLED.}

U ovom članku, autorke se bave pregledom postupaka digitalizacije kulturnog nasleđa $\mathrm{u}$ Republici Srbiji, kao i pregledom projekata koji su za predmet imali bilo kreiranje digitalnih podataka ili digitalizaciju starijih, već postojećih analognih podataka. Ovaj pregled za cilj ima da istraživačima zainteresovanim za postojeće stanje približi tok i razvoj digitalizacije u Srbiji, kao i da ukaže na potencijalne izazove, ali i mogućnosti za buduća istraživanja u oblasti očuvanja kultrnog nasleđa.

Još od 1990-tih dolazilo je do različitih pokušaja digitalizacije određenih delova srpskog kulturnog nasleđa. Ovi pokušaji su se odnosili kako na predmete koji se čuvaju u pojedinim muzejima, tako i na predmete i podatke do kojih se došlo arheološkim iskopavanjima. Međutim, svi ovi pokušaji su zapravo bili izolovani pojedinačni slučajevi. Glavna poteškoća je bila, a čini se i ostala, nedostatak standarda za unošenje i pohranjivanje digitalnih ili digitalizovanih podataka, tako da se često dešavalo da dođe do gubitka istih, usled zastarelosti bilo računarske 
opreme ili upotrebljenih računarskih programa.

Poslednjih godina, digitalizacija kulturnog nasleđa je postala imperativ za sve institucije koje se bave njegovom zaštitom. Zato je pokrenuta inicijativa da se na nacionalnom nivou uvede određena strategija i da se primeni u čitavoj zemlji. Iako je osnovni cilj da se u što većoj meri digitalizuje srpsko kulturno nasleđe, posebnu pažnju treba posvetiti dostupnosti tako dobijenih podataka, jer je lako moguće da dođe do njihove zloupotrebe. Takođe, potrebno je sprečiti prekomernu digitalizaciju. Zbog svega ovoga, neophodno je odrediti kako, zašto i u kojoj meri digitalizovati kulturno nasleđe.

Arheologija i prirodne nauke (Archaeology and Science) is an Open Access Journal. All articles can be downloaded free of charge and used in accordance with the licence Creative Commons - Attribution-NonCommercial-NoDerivs 3.0 Serbia (https://creativecommons.org/licenses/ by-nc-nd/3.0/rs/.

Časopis Arheologija i prirodne nauke je dostupan u režimu otvorenog pristupa. Članci objavljeni u časopisu mogu se besplatno preuzeti sa sajta i koristiti u skladu sa licencom Creative Commons - Autorstvo-Nekomercijalno-Bez prerada 3.0 Srbija (https://creativecommons.org/ licenses/by-nc-nd/3.0/rs/. 